\title{
PEMAKZULAN (IMPEACHMENT) PRESIDEN DALAM PERSPEKTIF HUKUM TATA NEGARA
}

\author{
Winarno Adi Gunawan ${ }^{1}$
}

\section{Abstrak}

This article provides explanation concerning the recent issue in Indonesia presidential institution that always becomes interesting research and debates. Focus of the author here is embarked on the presidential impeachment that has effective since post reformation in early second millennia. It has become most of debates and regards under the newly third amendment stipulation of the Constitution (UUD RI 1945). The issues regarding presidential impeachment have more clarification about it reasons, phase, and certain procedure to impeach the president and/or the vice president during their periods. The fundamental raison d'être of presidential impeachment is by their legitimating vanished which resulted by their act and conduct have violated laws either criminal and constitutional law violation including their oaths.

\section{Kata kunci: hukum tata negara, amandemen UUD 1945, mahkamah konstitusi, pemakzulan}

\section{Pendahuluan}

Sistem ketatanegaraan Indonesia mengalami perubahan yang sangat signifikan pasca perubahan (amandemen) Undang-Undang Dasar 1945 (UUD 1945). ${ }^{2}$ Perubahan tersebut meliputi sistem pelembagaan dan hubungan antar cabang-cabang kekuasaan negara (eksekutif, yudikatif dan legislatif), manajemen pemerintahan lokal serta relasinya dengan pemerintah pusat di Jakarta, jaminan konstitusional atas hak asasi manusia (HAM), dan berbagai sistem dalam penyelenggaraan negara seperti pemilihan umum (pemilu), dan sistem pertahanan dan keamanan nasional (hankamnas).

Perubahan yang cukup mendasar dalam sistem pelembagaan kekuasaan negara terjadi pada kedudukan Majelis Permusyawaratan Rakyat

${ }^{1}$ Penulis adalah Staf Jurnal Hukum dan Pembangunan FHUI.

${ }^{2}$ Perubahan Pertama (1999), Perubahan Kedua (2000), Perubahan Ketiga (2001) dan Perubahan Keempat (2002). 
(MPR). Sebagaimana diketahui bahwa sebelum amandemen UUD 1945, MPR merupakan lembaga tertinggi negara dan pelaksana tunggal kedaulatan rakyat. ${ }^{3}$ Dengan kedudukan semacam itu MPR layaknya super body yang mengatasi seluruh lembaga tinggi negara yang ada. Ditambah lagi MPR memiliki wewenang untuk menetapkan UUD dan Garis-Garis Besar Haluan Negara $(\mathrm{GBHN}),{ }^{4}$ memilih Presiden dan Wakil Presiden, ${ }^{5}$ serta mengubah UUD. ${ }^{6}$

Pasca amandemen UUD 1945 juga telah mengubah wajah lembaga perwakilan rakyat (legislatif) dengan munculnya lembaga baru yang bernama DPD. Meskipun DPD memiliki kewenangan yang sangat terbatas, tapi secara konstitusional kedudukannya sederajat (neben) dengan DPR. ${ }^{7}$ Beberapa ahli hukum tata negara menilai kemunculan DPD sebagai salah satu pilar penyangga kekuasaan legislatif menandai dimulainya penerapan sistem parlemen dua kamar (bikameral) di Indonesia.

Implikasi langsung dari perubahan UUD 1945 juga dapat dilihat dari munculnya kecenderungan legislative heavy dalam sistem ketatanegaraan Indonesia. Salah satu indikatornya yang terpenting adalah terjadinya peralihan kekuasaan membentuk UU dari tangan Presiden ke tangan DPR. Dalam ketentuan Pasal 5 ayat (1) UUD 1945 Naskah Asli dinyatakan: "Presiden memegang kekuasaan membentuk UU dengan persetujuan DPR". Melalui amandemen ketentuan tersebut diubah menjadi: "Presiden berhak mengajukan rancangan UU kepada DPR". ${ }^{8}$ Kemudian Pasal 20 ayat (1) UUD 1945 hasil Perubahan menyatakan: "DPR memegang kekuasaan membentuk UU". Rumusan ini mengubah ketentuan Pasal 21 ayat (1) UUD 1945 Naskah Asli yang menyatakan: "Anggota-anggota DPR berhak memajukan rancangan UU".

Kecenderungan legislative heavy juga tampak di dalam berbagai ketentuan UUD 1945 hasil perubahan yang mengharuskan adanya persetujuan DPR manakala Presiden ingin mengangkat Panglima Tentara Nasional Indonesia (TNI), Kapolri, dan duta besar yang akan ditempatkan di

\footnotetext{
${ }^{3}$ Pasal 1 ayat (2) UUD 1945 naskah asli.

${ }^{4}$ Pasal 3 UUD 1945 naskah asli.

${ }^{5}$ Pasal 6 ayat (2) UUD 1945 naskah asli.

${ }^{6}$ Pasal 37 UUD 1945 naskah asli.

${ }^{7}$ Pasal 22C dan 22D UUD 1945 hasil perubahan ketiga.

${ }^{8}$ Pasal 5 ayat (1) UUD 1945 perubahan pertama.
} 
negara-negara sahabat. UUD 1945 hasil perubahan juga melimpahkan sejumlah kewenangan baru kepada DPR. Beberapa diantaranya adalah wewenang mengusulkan pemberhentian Presiden dan/atau Wakil Presiden dalam masa jabatannya kepada MPR setelah ada putusan Mahkamah Konstitusi (MK) yang bersifat menerima, ${ }^{9}$ memberikan persetujuan atas UU bersama dengan Presiden, ${ }^{10}$ dan mengusulkan tiga orang calon hakim konstitusi kepada Presiden." Munculnya kewenangan baru ini seakan-akan memperjelas adanya kecenderungan legislative heavy dalam sistem ketatanegaraan di Indonesia.

Dalam domain yudikatif, hasil amandemen ketiga UUD 1945 telah melahirkan sebuah lembaga yang berfungsi sebagai pengawal konstitusi (the guardian of the constitution), yaitu Mahkamah Konstitusi yang mempunyai kedudukan setara derigan Mahkamah Agung, berdiri sendiri, serta terpisah (duality of jurisdiction) dengan Mahkamah Agung. Dalam menjalankan fungsinya mengawal konstitusi, berdasarkan Pasal 24C UUD Negara RI Tahun 1945 juncto Pasal 10 UU Nomor 24 Tahun 2003 tentang Mahkamah Konstitusi, Mahkamah mempunyai 4 (empat) kewenangan dan 1 (satu) kewajiban dengan perincian sebagai berikut:

1. menguji undang-undang terhadap UUD (judicial review);

2. memutus sengketa kewenangan lembaga negara yang kewenangannya diberikan oleh UUD (disputes regarding state institution's authority);

3. memutus pembubaran partai politik (political party's dissolution); dan

4. memutus perselisihan tentang hasil pemilihan umum (disputes regarding General Election's result); dan, wajib memberikan putusan atas pendapat DPR bahwa Presiden dan/atau Wakil Presiden telah melakukan pelanggaran hukum berupa pengkhianatan terhadap negara, korupsi, penyuapan, tindak pidana lainnya, atau perbuatan tercela, dan/atau pendapat bahwa Presiden dan/atau Wakil Presiden tidak lagi memenuhi syarat sebagai Presiden dan/atau Wakil Presiden (pemakzulan atau impeachment)..$^{12}$

\footnotetext{
${ }^{9}$ Pasal 7A UUD 1945 hasil perubahan ketiga.

${ }^{10}$ Pasal 20 ayat (2) UUD 1945 hasil perubahan kesatu.

${ }^{11}$ Pasal 24C ayat (3) UUD 1945 hasil perubahan.
} 
Wacana pemakzulan atau Impeachment belakangan ini kembali mengemuka terkait dengan kasus penerimaan dana tak wajar atau fiktif, yaitu penerimaan dana asing bahkan dana yang didapatkan dari tindakan yang terindikasi korupsi, termasuk dana non bujeter Departemen Kelautan dan Perikanan (DKP). Pasal 8 Ayat (3) UUD 1945 memang mengatur tentang pemakzulan. Akan tetapi pemakzulan merupakan situasi serius yang akan membawa pada implikasi-implikasi yang serius pula. Jika Pasal itu diberlakukan, maka dalam waktu 30 hari, Indonesia dipimpin oleh triumvirat (menlu, mendagri dan menhan). Dalam waktu 30 hari, MPR mengadakan sidang untuk memilih presiden dan wakil presiden dari pasangan yang diajukan parpol yang memperoleh suara terbanyak pertama dan kedua. ${ }^{13}$

Secara singkat, prosedur Pemakzulan dapat digambarkan sebagai berikut; Pertama, usul pemberhentian dapat diajukan oleh DPR kepada MPR hanya dengan terlebih dahulu mengajukan permintaan kepada MK untuk memeriksa, mengadili, dan memutus pendapat DPR bahwa Presiden melanggar ketentuan yang terdapat dalam Pasal 7A UUD 1945. Pengajuan permintaan DPR kepada MK hanya dapat dilakukan dengan dukungan sekurang-kurangnya $2 / 3$ dari jumlah anggota DPR yang hadir dalam sidang paripurna yang dihadiri oleh sekurang-kurangnya $2 / 3$ dari jumlah anggota DPR. ${ }^{14}$

Dari proses awal di DPR, dimulai pelaksanaan fungsi pengawasan berupa penggunaan Hak Interpelasi, yaitu hak untuk meminta keterangan kepada pemerintah mengenai kebijakan pemerintah yang penting dan strategis serta berdampak luas pada kehidupan bermasyarakat dan bernegara; dan Hak Angket, yaitu hak untuk melakukan penyelidikan terhadap kebijakan pemerintah yang penting dan strategis serta berdampak luas pada kehidupan bermasyarakat dan bernegara yang diduga bertentangan dengan peraturan perundang-undangan. Patut dicermati bahwa dalam hal ini digunakan kuorum tidak sederhana, yaitu kuorum $2 / 3$; sedangkan sehingga

${ }^{12}$ Pan M. Faiz, “Menabur Benih Constitutional Complaint”, <http://jurnalhukum. Blogspot.com/2006/09/constitutional-complaint-dan-hak-asasi.html>, diakses tanggal 21 Maret 2007

13 Antara News - Lembaga Kantor Berita Nasional, "Ketua MPR Tolak Wacana Pemakzulan Presiden Terkait Dana DKP", <http://www.antara.co.id/arc/2007/5/29/ketuampr-tolak-wacana-pemakzulan-presiden-terkait-dana-dkp/>, diakses tanggal 8 Juni 2007.

14 Saldi Isra, “Prosedur Konstitusional Pemakzulan Presiden", makalah disampaikan dalam Seminar Nasional Teknik Konstitusional Impeachment Presiden, Jakarta, 28 Februari 2007. 
kini belum ada mekanisme dalam tata-tertib DPR yang khusus mengatur prosedur pemakzulan ini. ${ }^{15}$

Kedua, proses berlanjut ke Mahkamah Konstitusi. Dalam waktu paling lama 90 hari setelah permintaan DPR, MK wajib memeriksa, mengadili, dan memutus dengan seadil-adilnya pendapat DPR. Kemungkinan amar putusan MK ajalah sebagai berikut:

1. Permohonan tidak dapat diterima, apabila permohonan tidak memenuhi syarat;

2. Membenarkan pendapat DPR, apabila terbukti melakukan pelanggaran pasal pemakzulan; dan

3. Permohonan ditolak, tidak terbukti melakukan pelanggaran pasal pemakzulan. Apabila Amar Putusannya adalah alternatif kedua, maka sebagai langkah ketiga, DPR menyelenggarakan sidang paripurna untuk meneruskan usul pemberhentian kepada MPR. MPR wajib menyelenggarakan sidang untuk memutuskan usul DPR paling lambat 30 hari sejak MPR menerima usul tersebut. ${ }^{16}$

Keputusan harus diambil dalam rapat paripurna MPR yang dihadiri oleh sekurang-kurangnya 3/4 dari jumlah anggota dan disetujui oleh sekurang-kurangnya $2 / 3$ dari jumlah anggota yang hadir, setelah Presiden diberi kesempatan menyampaikan penjelasan dalam rapat paripurna MPR. Jadi, putusan di MPR Mayoritas bersifat absolut. Pemakzulan oleh karena itu tergantung pada dua hal pokok, yaitu: "Pintu masuk" atau alasan-alasan yang dapat memenuhi pasal pemakzulan; dan, Dukungan atau konstelasi politik di DPR (dan DPD) yang mendukung dilakukan pemakzulan. Pintu masuk lebih mudah menemukannya, misalnya melakukan tindak pidana korupsi. ${ }^{17}$

Korupsi dapat didakwakan dalam pemakzulan presiden karena, sebagaimana dijelaskan di atas, penerimaan dana non-bugeter DKP tersebut dapat diklasifikasikan sebagai tindak pidana korupsi; dan karenanya, dapat dijadikan pintu masuk pemakzulan presiden, yang salah satu pasal pemakzulannya adalah korupsi.

Pembahasan ini khususnya akan mencermati kewenangan MK dalam memutus pendapat DPR bahwa Presiden diduga telah melakukan pelanggaran hukum berupa pengkhianatan terhadap negara, korupsi, penyuapan, tindak pidana berat lainnya, atau perbuatan tercela, dan/atau

\section{${ }^{15}$ Ibid. \\ ${ }^{16}$ Ibid. \\ ${ }^{17}$ Ibid.}


tidak lagi memenuhi syarat sebagai Presiden sebagaimana dimaksud dalam UUD 1945.

Masalah ada atau tidaknya implikasi yuridis (akibat hukum) dari putusan MK dalam hal pemakzulan penting diteliti karena:

1. UUD 1945 hasil perubahan sama sekali tidak menyinggung tentang ada atau tidak adanya implikasi yuridis (akibat hukum) putusan MK dalam masalah pemakzulan. Hal yang sama juga tidak diatur secara jelas dalam UU No. 24 Tahun 2003 tentang Mahkamah Konstitusi maupun Peraturan Mahkamah Konstitusi yang dijadikan dasar Hukum Acara Mahkamah Konstitusi;

2. Sampai saat ini belum ada satupun pendapat hukum yang secara khusus menyoroti masalah ini sehingga persoalan ada atau tidak adanya implikasi yuridis (akibat hukum) MK dalam masalah pemakzulan tetap menjadi wilayah abu-abu (grey area) dalam sistem ketatanegaraan Indonesia.

3. Belajar dari pengalaman Indonesia pasca Proklamasi 1945 yang sudah mengalami dua kali pergantian kekuasaan dengan cara pemakzulan, yakni terhadap Presiden Soekarno dan Presiden Abdurrahman Wahid, seyogyanya masalah ada atau tidak adanya implikasi yuridis (akibat hukum) putusan MK dalam masalah pemakzulan segera diperjelas demi kepastian hukum dalam sistem ketatanegaraan Indonesia.

Urgensi untuk memperjelas masalah ini semakin tinggi mengingat usulan pemakzulan yang diajukan DPR kepada MK bisa berakhir dengan tiga kemungkinan berikut ini: Pertama, MK menolak atau tidak dapat menerima pendapat/usul DPR tentang pemakzulan. Akibatnya proses pemakzulan tidak bisa dilanjutkan ke Sidang Istimewa MPR; Kedua, MK menerima/ membenarkan pendapat atau usul DPR tentang pemakzulan, kemudian MPR menggelar Sidang Istimewa MPR yang berujung dengan pemberhentian presiden; Ketiga, MK menerima/membenarkan pendapat atau usul DPR tentang pemakzulan, namun Sidang Istimewa MPR memutuskan untuk tidak memberhentikan Presiden. ${ }^{18}$

Jika yang terjadi adalah kemungkinan pertama, maka tidak akan terjadi konflik konstitusional yang serius. Kalaupun yang terjadi adalah kemungkinan kedua, jika Sidang Istimewa MPR menyetujui pemakzulan, maka mantan Presiden yang diberhentikan karena diduga telah melakukan tindak pidana berat atau korupsi misalnya, dapat dipidana atas tindakan yang

${ }^{18}$ Maruarar Siahaan, "Hukum Acara Mahkamah Konstitusi", (Jakarta: Konstitusi Press, 2005). hal. 79. 
dilakukannya di pengadilan biasa. Dalam keadaan seperti itu, pendapat hukum MK yang dijadikan alasan yuridis pemakzulan oleh Sidang Istimewa MPR bisa dijadikan dasar pemidanaan di pengadilan.

Konflik konstitusional yang serius baru muncul bila yang terjadi adalah kemungkinan ketiga. Permasalahan pertama yang muncul adalah dapatkah putusan MK dijadikan dasar pemidanaan terhadap Presiden yang lolos dari proses pemakzulan. Kemudian, Jika putusan MK dapat dijadikan dasar pemidanaan terhadap Presiden yang lolos dari proses pemakzulan, masalah berikutnya adalah pengadilan mana yang berwenang mengadili perkara ini. Belum ada kejelasan pengaturan hukum mengenai apakah dalam statusnya sebagai tersangka, seorang Presiden harus berstatus non aktif dari jabatannya.

Maruarar Siahaan, seorang hakim konstitusi, berpendapat bahwa akan lebih baik bila penjelasan masalah ini baru dituntaskan setelah ada kasusnya agar bisa menjadi yurisprudensi dalam tata hukum. ${ }^{19}$ Padahal penjelasan ini seharusnya sudah diberikan oleh perangkat peraturan hukum sebelum kasusnya itu sendiri terjadi. Terlepas dari putusan Mahkamah Konstitusi yang menerima dan membenarkan pendapat DPR untuk memakzulkan Presiden, namun putusan itu tidak dikuatkan dalam Sidang Istimewa MPR, yang berakibat presiden yang bersangkutan lolos dari pemakzulan, maka akan timbul berbagai kesulitan dalam menyelenggarakan proses peradilan pidana terhadap presiden itu atas tindak pidana yang dilakukannya, yang padahal merupakan dasar pendapat DPR mengenai pemakzulan dirinya. Hal ini dapat menyebabkan terjadinya pengingkaran terhadap prinsip kesetaraan di muka hukum, bahkan menimbulkan suasana ketidakpastian hukum yang berujung pada krisis konstitusional dan politik yang serius.

\section{Sejarah Pemakzulan di Indonesia}

Sejarah bangsa kita ibarat seumur jagung. Dalam tenggang waktu 1945-2001, lebih kurang 56 tahun telah mengalami empat presiden dan yang kini sedang berkuasa belum akan disimak untuk dicatat. Empat presiden dengan tenggang waktu rata-rata 14 tahun masa kerja yang seharusnya ratarata delapan tahun, sehingga ada kelebihan enam tahun untuk seorang presiden.

Sejarah mencatat bahwa dari empat Presiden itu, dua memiliki masa kerja yang panjang dengan pelbagai catatan masing-masing yang untuk sementara belum akan ditimbang dengan neraca kebaikan atau keburukan. 
Dua lainnya memiliki masa kerja yang relatif sangat pendek, juga dengan neraca baik buruk yang belum akan dianalisis di sini. Masing-masing oleh sementara orang diberi karikatur lelucon karakterisasi yang kurang menyenangkan.

Dalam sejarah ketatanegaraan Indonesia, ada dua Presiden yang diberhentikan di tengah masa jabatannya yaitu Presiden soekarno pada masa orde lama dan Presiden Abdurahman Wahid pada masa orde reformasi. Dari pengalaman ketatanegaraan ini, kita dapat melihat apa yang menjadi alasan utama pemberhentian Presiden, yaitu karena presiden kehilangan legitimasi yang sedemikian rupa karena tindakan dan perbuatannya yang dapat dikatagorikan sebagai perbuatan melanggar hukum baik hukum pidana maupun hukum ketatanegaraan atau pelanggaran konstitusi termasuk pelanggaran sumpah jabatan. ${ }^{20}$

Dilihat dari sudut hukum tata negara, studi mendalam untuk menganalisis proses dan prosedur pemberhentian presiden mempunyai makna akademis dan praktis yang sangat penting. ${ }^{21}$ Disamping itu, hal yang lebih penting lagi adalah alasan seorang presiden dapat diberhentikan sebagai presiden dalam masa jabatannya menurut UUD 1945. pengalaman Ketatanegaraan Negara Republik Indonesia yang sangat menarik adalah bagaimana pemberhentian presiden Soekarno dan presiden Abdurahman Wahid dalam masa jabatannya. Presiden Soekarno diberhentikan dari masa jabatan presiden karena pertanggung jawabannya ditolak oleh Majelis Permusyawaratan Rakyat Sementara (MPRS) berkaitan dengan peristiwa Pemberontakan G-30 S/PKI 1965 yang merupakan tindak pidana makar.

UUD 1945 sebelum dilakukan perubahan, tidak memberikan aturan yang terperinci tentang pemberhentian presiden ditengah masa jabatannya, baik alasan-alasan maupu prosedurnya. Satu-satunya ketentuan dalam UUD 1945 sebelum perubahan, yang secara implisit mengatur tentang kemungkinan pemberhentian presiden ditengah masa jabatannya adalah 8 Undang-undang Dasar 1945 yang berbunyi:

Jika presiden mangkat, berhenti atau tidak dapat melakukan kewajibannya dalam masa jabatannya ia diganti oleh Wakil Presiden sampai habis masa jabatannya.

117.

${ }^{20}$ Zoelva Hamdan, "Impeachment Presiden", (Jakarta: Konstitusi Press, 2005), hal.

${ }^{21}$ Sabar Sitanggang, et.al. (Editor), "Catatan Kritis dan Percikan Pemikiran Yusril Ihza Mahendra", (Jakarta: Bulan Bintang, 2001), hal. 231. 
Dalam penjelasan UUD 1945 angka VII Alinea ketiga ${ }^{22}$ menentukan:

\begin{abstract}
Jika Dewan menganggap bahwa presiden sungguh melanggar haluan negara yang telah ditetapkan oleh UUD atau oleh MPR, maka Majelis itu dapat diundang untuk persidangan istimewa agar supaya bisa meminta pertanggung jawaban presiden.
\end{abstract}

Dalam hal MPR, tidak memberhentikan presiden, bukanlah berarti MPR menganulir putusan Mahkamah Konstitusi yang membenarkan pendapat DPR adanya dugaan pelanggaran hukum oleh presiden. Karena itu selanjutnya Presiden dapat saja dituntut secara pidana melalui peradilan pidana biasa manakala ada dugaan tindak pidana yang dilakukan oleh presiden. Proses pemberhentian presiden itu sebagai sebuah proses peradilan yang spesifik yang tidak sama dengan peradilan biasa dalam pengadilan pidana. Memperhatikan ketentuan-ketentuan dan praktek ketatanegaraan mengenai proses pemberhentian presiden baik dalam ketatanegaraan Indonesia maupun di negara lain, proses pemberhentian presiden adalah sangat terkait dengan masalah politik diparlemen (DPR serta MPR) menganggap perbuatan yang dilakukan oleh presidennya layak untuk menjadi alasan pemberhentian. Karena itu dalam proses peradilan pemberhentian presiden, bukanlah pertanggung jawaban pidana yang menjadi fokus perhatiannya, akan tetapi adalah pertanggungjawaban politik.

Setelah (mantan Presiden) Soekarno "direbut kekuasaan" oleh (mantan Presiden) Soeharto, ternyata konstitusi seolah-olah diberi pemahaman baru sedemikian rupa sehingga menjadi sesuatu yang sakral. Dan para pengikutnya ikut dengan giat dan tekun mensakralkan sepak terjang mereka. Dari suatu perspektif tertentu, sejarah seperti berulang. (Mantan Presiden) Soeharto "diturunkan" oleh para mahasiswa, tetapi sebetulnya para kroni Soeharto ikut menjadi Brutus yang sangat lihai. Entah itu karena belajar dari sejarah Mataram ataupun Majapahit, para elit politik yang acapkali tanpa rasa malu mengklaim diri mereka sebagai penyambung lidah rakyat, berkolusi dalam bentuk konspirasi, bukan saja untuk menjatuhkan, tetapi juga untuk menyelamatkan diri mereka yang sesungguhnya sudah tercemar dengan segala macam bentuk KKN.

Pendulum kekuasaan berayun dari pihak eksekutif ke pihak legislatif. Entah sadar atau tidak, entah karena mabuk kemenangan, entah karena merasa terpanggil oleh sejarah untuk suatu tugas mulia, para "legislator" ini acapkali mengalami transformasi sebagai alligator. Konstitusi katanya

${ }^{22}$ Berdasarkan ketentuan II Aturan Tambahan yang ditetapkan dalam Perubahan Keempat UUD 1945, Penjelasan UUD 1945 bukan lagi bagian dari UUD 1945. 
diamandemen, tetapi ternyata "dibongkar pasang". Panitia ahli diundang untuk menjaga agar semua berjalan dalam koridor ketatanegaraan yang benar, ternyata saling "harassment", memperlihatkan keilmiahan semu sebab very loaded with political flavour. Tidak ada kesadaran bahwa kini saatnya untuk memperlihatkan bahwa sebagai orang kampus tidak perlu menyontek, kecuali sekedar membandingkan untuk dicari mana yang berhikmat dan mana sekedar retorika.

Mengkaji pembatasan kewenangan seorang Presiden, seharusnya dimulai dari konstitusi. Apakah mungkin kalau konstitusi tidak mengatur, lalu hal itu diatur dengan TAP. Ini suatu kajian yuridis yang sangat menarik. Kalau TAP juga hanya mengatur dalam garis besar apakah itu berarti implementasinya harus diatur lebih lanjut dengan undang-undang.

Menanggapi perkembangan politik dalam negeri yang semakin memanas serta pro-kontra yang ada, presiden Soekarno, selaku Mandataris MPRS, pada tanggal 22 Juni 1965 menyampaikan laporan pertanggungjawaban kepada MPRS yang dikenal dengan Nawaksara. Beberapa pokok isi pidato Nawaksara tersebut adalah:

1. Ajakan melakukan retrospeksi tentang posisi presiden sebagai pemimpin Besar Revolusi, Mandataris MPRS serta presiden Seumur Hidup;

2. Laporan pertanggungjawaban presiden Soekarno mengenai pelaksanaan garis-garis besar haluan negara yang terkandung dalam Ketetapan MPRS No. I dan II tahun 1960, yaitu pelaksanaan Trisakti; yaitu berdaulat dan bersdikari dalam ekonomi;

3. Pelaksanaan tugas yang berkaitan dengan pembangunan politik dan pembangunan ekonomi;

4. Penjelasan lainnya tentang Demokrasi Terpimpin, pelaksanaan GBHN yang akan dibicarakan di DPR, rencana pemurnian pelaksanaan UUD 1945 dan terkait dengan tugas MPR/S serta kedudukan presiden dan wakil presiden.

Pertanyaan lain, apakah semua yang diinginkan oleh legislatif harus diatur secara detail, secara jelimet. Kemudian akan timbul pertanyaan lain, apakah mungkin hal itu diatur dengan konvensi. Kalau ya, sampai seberapa jauh konvensi akan ditata dan ditaati dan siapa yang akan menjadi watch dog bertalian dengan pelaksanaan konvensi itu.

Dewasa ini sudah diatur masa kerja seorang presiden. Itu sudah betul dan sangat baik. Mekanisme untuk itu tidak sulit dan sudah diatur dalam konstitusi. Tetapi bagaimana dengan mekanisme "impeachment" misalnya. Bagaimana dengan hadiah-hadiah mahal yang diterima seorang presiden. 
Apakah seorang presiden bisa selama masa kekuasaannya membentuk atau menghapus departemen. Apakah semua sepak terjang seorang presiden harus mendapatkan persetujuan atau pertimbangan dari pihak legislatif. Bagaimana pula pertimbangan kekuasaan atau kewenangan antara eksekutif, legislatif, dan yudikatif. Kalau sampai suatu konflik timbul, apakah untuk itu harus bertindak misalnya, Mahkamah Konstitusi. Lalu bagaimana mekanisme kerja dan prosedur operasionalnya.

Adapun mekanisme pemberhentian presiden Soekarno, lebih dominan dilakukan pada tingkat MPRS, baik mengenai permintaan pertanggung jawab presiden maupun pengkajian terhadap alasan-alasan pemberhentiannya. Sedangkan peranan DPR hanya secara formal konstitusional menyampaikan resolusi dan memorandum yang meminta MPRS untuk melaksanakan Sidang Istimewa MPRS memberhentikan presiden. ${ }^{23}$

Kasus Rp 35 miliar dana Yanatera Bulog yang melahirkan Memorandum I dan II berakhir dengan jatuhnya Presiden K.H. Abdurrahman Wahid. Dia adalah satu-satunya Presiden yang terkena impeachment, setelah melalui tahap demi tahap yang memakan waktu cukup lama. Proses pemberhentian presiden Abdurrahman Wahid diawali oleh maraknya polemik di media massa mengenai dana Yanatera Bulog sebesar Rp 35 milyar dan dana bantuan Sultan Brunei Darussalam sebesar US \$ 2 juta yang mengaitkan nama presiden Abdurrahman Wahid. Hal ini kemudian memicu 236 anggota DPR untuk mengajukan usul menggunakan hak mengadakan penyelidikan terhadap kedua kasus tersebut.

Usul tersebut disetujui DPR RI pada Rapat Paripurna tanggal 28 agustus 2000, dan secara resmi Panitia Khusus (Pansus) DPR RI untuk mengadakan penyelidikan terhadap kedua kasus tersebut di bentuk pada tanggal 5 september $2000 .{ }^{24}$ Setelah Pansus bekerja selama 4,5 bulan, Panitia Khusus telah selesai melaksanakan tugasnya dan melaporkan hasilnya pada Rapat Paripurna DPR RI pada tanggal 5 Januari 2001.

Kesimpulan dari hasil penyelidikan tersebut adalah:

${ }^{23}$ Ketetapan Majelis Permusyawaratan Rakyat Sementara No. XXXIII/MPRS/1967 tentang Pencabutan Kekuasaan Pemerintahan Negara dari Presiden Soekarno.

${ }^{24}$ Keputusan DPR RI No. 05/DPRRI/2000-2001, Tanggal 5 September 2000, Tentang Pembentukan Panitia Khusus Dewan Perwakilan Rakyat RI untuk Mengadakan Penyelidikan terhadap Kasus Dana Milik Yayasan Kesejahteraan Karyawan (YANATERA) Badan Urusan Logistik (BULOG) dan Kasus Dana Bantuan Sultan Brunei Darussalam Kepada Presiden K.H Abdurrahman Wahid. 
1. Dalam Kasus Dana YANATERA BOLUG, Pansus berpendapat" patut diduga bahwa Presiden Abdurrahman Wahid berperan dalam pencairan dan penggunaan dana Yanatera Bulog";

2. Dalam kasus dana bantuan Sultan Brunei Darrussalam Pansus berpendapat: "Adanya inkonsistensi pernyataan Presiden Abdurrahman Wahid Tentang masalah bantuan Sultan Brunei Darrussalam, menunjukan bahwa presiden telah menyampaikan keterangan yang tidak sebenarnya kepada masyarakat " . 25

Sehubungan dengan hasil kerja dan kesimpulan Pansus tersebut, Paripurna DPR RI memutuskan:

1. Menerima dan menyetujui laporan hasil kerja Pansus dan memutuskan untuk di tinjaklanjuti dengan menyampaikan Memorandum untuk mengingatkan bahwa Presiden K.H. Abdurrahman Wahid sungguh melanggar haluan negara, yaitu: 1) melanggar UUD 1945 pasal 9 Tentang Sumpah Jabatan, dan; 2) melanggar Ketetapan MPR RI No.XI/MPR/ 1998 Tentang Penyelenggaraan Negara Yang Bersih dan Bebas dari KKN";

2. Hal-hal yang berkaitan dengan dugaan adanya pelanggaran hukum, menyerahkan persoalan ini untuk di proses berdasarkan ketentuan hukum yang berlaku. ${ }^{26}$

Dalam Memorandum DPR terhadap Presiden Abdurrahman Wahid tersebut, ada dua pelanggaran haluan negara yang dituduhkan oleh DPR dilakukan oleh Presiden Aburrahman Wahid adalah:

a. Melanggar UUD RI Tahun 1945 Pasal mengnai Sumpah Jabatan Presiden;

b. Melanggar Ketetapan Majelis MPR RI No.XI /MPR/1998 Tentang Penyelenggaraan Negara Yang Bersih dan Bebas dari Korupsi, Kolusi dan Nepotisme. ${ }^{27}$

Dengan dasar keputusan tersebut, DPR RI menyampaikan Memorandum Pertama kepada Presiden pada tanggal 1 Februari 2001 yang

${ }^{25}$ Laporan Panitia Dewan Perwakilan Rakyat RI untuk mangadakan penyelidikan terhadap kasus Dana milik Yayasan dana Yanatera Bulog dan Kasus Dana Bantuan Sultan Brunei Darrussalam kepada Presiden K.H. Abdurrahman Wahid pada Tanggal 29 Januari 2001.

${ }^{26}$ Keputusan Rapat Paripurna DPR RI Tanggal 1 Februari 2001.

27 Keputusan DPR RI No.33/DPRRI/III/2000-2001, Tanggal 1 Februari 200, Tentang Penetapan Memorandum DPR RI Kepada Presiden K.H. Abdurrahman Wahid. 
di susul dengan Memorandum kedua pada tanggal 1 Mei 2001 dan keputusan untuk mengadakan Sidang Istimewa MPR RI pada tanggal 1-7 agustus untuk meminta pertanggungjawaban Presiden Abdurrahman Wahid.

Serunya perbedaan persepsi antara Presiden Abdurahman Wahid dan DPR tentang alasan pemberhentiannya membuka mata hati MPR untuk segera membentuk suatu lembaga yang bisa menyelesaikan secara adil bila sengketa seperti itu terjadi di kemudian hari. Presiden Abdurahman Wahid dijatuhkan dalam Sidang Istimewa MPR karena di nilai sungguh-sungguh melanggar haluan negara, sementara presiden menilai dasar yang digunakan MPR menjatuhkannya tidak kuat dan inkonstitusional. ${ }^{28}$

Selama ini, bila terjadi seteru atau sengketa kewenangan antar lembaga negara, tidak ada suatu lembaga yang secara mandiri dan objektif menyelesaikannya. Memang ada Majelis Permusyawaratan Rakyat selaku lembaga tertinggi sebelum perubahan UUD 1945 yang diberi wewenang menangani seteru antara Dewan Perwakilan Rakyat dan Presiden, tetapi independensi dan objektivitasnya diragukan.

\section{Pemakzulan Dalam Peraturan Perundang-Undangan di Indonesia}

\section{A. Menurut UUD 1945}

Usaha untuk menciptakan kekuasaan kehakiman yang merdeka dan bertanggung jawab menjadi semakin besar dalam era reformasi, mengingat reformasi sendiri harus diartikan sebagai usaha rasional dan sistematik dari seluruh bangsa Indonesia untuk mengaktualisasikan nilai-nilai dasar demokrasi.

Mahkamah Konstitusi merupakan salah satu lembaga negara yang melakukan kekuasaan kehakiman yang merdeka untuk menyelenggarakan peradilan guna menegakan hukum dan keadilan. Lembaga ini memiliki visi "tegaknya konstitusi dalam rangka mewujudkan cita-cita negara hukum dan demokrasi demi kehidupan kebangsaan dan kenegaraan yang bermartabat" ${ }^{29}$

Mahkamah Konstitusi lahir dengan tugas utama untuk menjaga konstitusi selurus-lurusnya. Kewenangan Mahkamah Konstitusi untuk

28 Mas Marwan, "Merefleksi Wewenang Mahkamah Konstitusi dalam Menguji Undang-undang”, (Jakarta: Konstitusi Press, 2004), hal. 268.

29 Mahkamah Konstitusi Republik Indonesia. "Booklet tentang Sejarah Pembentukan, Visi dan Misi Mahkamah Konstitusi RI", (Jakarta: Penerbit Mahkamah Konstitusi RI, 2006), hal. 4. 
menguji UU terhadap UUD adalah wujud nyata untuk menjaga konstitusionalitas UU. Selain itu, bilamana terjadi sengketa kewenangan antarlembaga negara, maka Mahkamah Konstitusilah yang akan memberikan putusan terakhir yang bersifat final dan mengikat. "Putusan Mahkamah Konstitusi tersebut adalah salah satu kewenangan Mahkamah Konstitusi yang diberikan oleh UUD 1945". Sedangkan menyangkut impeachment Presiden/Wakil Presiden yang diajukan oleh DPR, sebelum terjadinya perubahan UUD 1945 mekanisme penyelesaiannya lebih bersifat politis. Tetapi sejak Mahkamah Konstitusi berdiri proses impeachment dilaksanakan berdasarkan atas dasar hukum. "Namun demikian impeachment tidak mudah dilaksanakan, selain karena syaratnya berat juga akan membawa dampak sosial politik yang besar".

Untuk mengetahui lebih jelasnya, disini penulis akan mencoba menjelaskan atau memaparkan sedikit apa arti dari Impeachment itu sendiri. Secara harfiah impeachment itu sendiri diartikan sebagai pendakwaan atau dapat juga diartikan sebagai pemberhentian Presiden dan/atau Wakil Presiden ditengah masa jabatannya. Adapaun pengaturan impeachment itu sendiri sebenarnya telah diatur dalam UUD 1945 dalam pasal 7A dan 7B. Untuk diketahui, alasan yang menyebabkan Presiden dan/atau wakil Presiden itu dapat di-impeach adalah pengkhinatan terhadap negara, korupsi, penyuapan, tindak pidana berat lainnya, atau perbuatan tercela maupun apabila terbukti tidak lagi memenuhi syarat sebagai Presiden dan/atau Wakil Presiden dan dapat juga dikatakan Presiden dan/atau Wakil Presiden melanggar sumpah jabatannya. ${ }^{30}$

Pemakzulan itu sendiri adalah sebuah proses di mana sebuah badan legislatif secara resmi menjatuhkan dakwaan terhadap seorang pejabat tinggi negara. Pemakzulan bukan selalu berarti pemecatan atau pelepasan jabatan, namun hanya merupakan pernyataan dakwaan secara resmi, mirip pendakwaan dalam kasus-kasus kriminal, sehingga hanya merupakan langkah pertama menuju kemungkinan pemecatan. Saat pejabat tersebut telah dimakzulkan, ia harus menghadapi kemungkinan dinyatakan bersalah melalui sebuah pemungutan suara legislatif, yang kemudian menyebabkan pemecatan sang pejabat.

${ }^{30}$ Putra Hendrasyah. "Impeachment Presiden", <http://www.pontianakpost.com/ berita index.asp?Berita=Opini\&id=131841>, diakses tanggal 21 Maret 2008. 


\section{B. Menurut UU No. 24 Tahun 2003}

Salah satu hal yang menjanjikan bagi perbaikan ketatanegaraan dalam perubahan amandemen Undang-Undang Dasar 1945 adalah pembentukan Mahkamah Konstitusi sebagai pelaksana kekuasaan kehakiman bersama Mahkamah Agung yang diatur dalam pasal 24 ayat (2) UUD 1945. Kehadiran Mahkamah Konstitusi dalam sistem Ketatanegaran Indonesia setelah empat kali amandemen UUD 1945 merupakan bagian dari reformasi konstitusi untuk mencegah penyelenggaraan kekuasaan yang otoriter dan tidak dapat dikontrol. ${ }^{31}$ Bahkan bisa membawa pencerahan baru dalam kehidupan Ketatanegaraan Indonesia. Kehadiran Mahkamah Konstitusi diharapkan mampu secara obyektif menyelesaikan secara adil dan mandiri bila sengketa seperti itu kembali terjadi.

Dalam pasal 24C ayat (1) UUD 1945 menegaskan bahwa Mahkamah Konstitusi mempunyai kewenangan untuk:

1. Menguji (judicial review) undang-undang terhadap UUD;

2. Memutus sengketa kewenangan lembaga negara yang kewenangannya diberikan oleh UUD;

3. Memutus pembubaran parpol;

4. Memutus perselisihan tentang hasil pemilihan umum;

5. Wajib memberikan putusan atas pendapat DPR mengenai dugaan pelanggaran oleh presiden dan/atau wakil presiden menurut UUD.

Dari lima kewenangan Mahkamah Konstitusi tersebut hanya satu kewenangan yang akan dibahas yaitu kewenangan mengenai memberikan putusan atas pendapat DPR mengenai dugaan pelanggaran oleh presiden dan/atau wakil presiden. ${ }^{32}$

Dalam hal ini, Mahkamah Konstitusi wajib memberikan putusan atas pendapat DPR bahwa Presiden dan/atau Wakil Presiden diduga telah melakukan pelanggaran-pelanggaran hukum berupa:

1. pengkhianatan terhadap negara dalam bentuk tindak pidana terhadap keamanan negara sebagaimana diatur dalam undangundang;

2. korupsi dan penyuapan dalam bentuk tindak pidana korupsi atau penyuapan sebagaimana diatur dalam undang-undang; dan/atau,

${ }^{31}$ Mas Marwan, Loc. Cit, hal. 267-268.

32 Taufiqurahman Syahuri, Lima Kewenangan Mahkamah Konstitusi dan Satu Tahun Pelaksanaannya, (Jakarta: Konstitusi Press, tanpa tahun), hal. 360-361. 
3. tindak pidana berat lainnya yang diancam dengan pidana penjara 5 (lima) tahun atau lebih; atau

4. perbuatan tercela berupa perbuatan yang dapat merendahkan martabat Presiden dan/atau Wakil Presiden; atau

5. tidak lagi memenuhi syarat sebagai Presiden dan/atau Wakil Presiden sebagaimana ditentukan dalam Pasal 6 Undang-Undang Dasar Negara Republik Indonesia Tahun 1945.

Sebagaimana yang diatur dalam undang-undang Mahkamah Konstitusi bahwa pengkhianatan terhadap negara adalah tindak pidana terhadap keamanan negara yang diatur dalam Undang-undang. Maka dapat dikemukakan bahwa sebagian besar tindak pidana terhadap keamanan negara diatur dalam Kitab Undang-undangHukum Pidana (KUHPidana) dan sebagian diluar KUHPidana, seperti tindak pidana terorisme. Soesilo berpendapat bahwa pada hakekatnya kepentingan negara dan pemerintahannya adalah kepentingan seluruh rakyat Indonesia dan kejahatan terhadap negara dan pemerintahannya harus dipandang sebagai pengkhianatan terhadap kepentingan rakyat. ${ }^{33}$

\section{Mekanisme Pemakzulan Dalam Peraturan Perundang-Udangan di Indonesia}

Mekanisme atau prosedur pemberhentian Presiden diatur dalam Pasal 7B UUD 1945. berdasarkan ketentuan UUD ini, lembaga negara yang diberi kewenangan untuk memberhentikan Presiden dalam masa jabatannya adalah Majelis Permusyawaratan Rakyat (MPR). Namun sebelum diputus oleh MPR, proses pemberhentian Presiden dimulai dari proses pengawasan terhadap Presiden oleh DPR. Apabila dari pengawasan itu, di temukan adanya pelanggaran hukum yang dilakukan oleh Presiden berupa: penghianatan terhadap negara, korupsi, penyuapan dan tindakan pidana berat lainnya serta perbuatan tercela atau Presiden tidak lagi memenuhi syarat sebagai Presiden, maka DPR dengan dukungan 2/3 (dua per tiga) jumlah suara dapat mengajukan usulan pemberhentian Presiden kepada MPR, dengan terlebih dahulu meminta putusan dari Mahkamah Konstitusi tentang kesimpulan dan pendapat dari DPR.

Dengan demikian pemberhentian Presiden menurut UUD 1945, harus melewati 3 (tiga) lembaga negara.

\footnotetext{
${ }^{33}$ R. Soesilo, hal. 109.
} 


\section{A. Pengajuan Usul oleh DPR}

Secara singkat, mekanisme atau prosedur Pemakzulan dapat digambarkan sebagai berikut; Pertama, usul pemberhentian dapat diajukan oleh DPR kepada MPR hanya dengan terlebih dahulu mengajukan permintaan kepada MK untuk memeriksa, mengadili, dan memutus pendapat DPR bahwa Presiden melanggar ketentuan yang terdapat dalam Pasal 7A UUD 1945. Pengajuan permintaan DPR kepada MK hanya dapat dilakukan dengan dukungan sekurangkurangnya $2 / 3$ dari jumlah anggota DPR yang hadir dalam sidang paripurna yang dihadiri oleh sekurang-kurangnya $2 / 3$ dari jumlah anggota DPR. ${ }^{34}$

Dari proses awal di DPR, dimulai pelaksanaan fungsi pengawasan berupa penggunaan Hak Interpelasi, yaitu hak untuk meminta keterangan kepada pemerintah mengenai kebijakan pemerintah yang penting dan strategis serta berdampak luas pada kehidupan bermasyarakat dan bernegara; dan Hak Angket, yaitu hak untuk melakukan penyelidikan terhadap kebijakan pemerintah yang penting dan strategis serta berdampak luas pada kehidupan bermasyarakat dan bernegara yang diduga bertentangan dengan peraturan perundangundangan. Patut dicermati bahwa dalam hal ini digunakan kuorum tidak sederhana, yaitu kuorum 2/3; sedangkan sehingga kini belum ada mekanisme dalam tata-tertib DPR yang khusus mengatur prosedur pemakzulan ini. ${ }^{35}$

Tatib DPR menetapkan untuk mengusulkan penggunaan hak menyatakan pendapat maka diperlukan jumlah pengusul sedikitnya 13 orang anggota DPR. Setelah memenuhi syarat, usulan ini disampaikan secara tertulis kepada pimpinan DPR untuk kemudian disampaikan kepada anggota DPR lainnya melalui Rapat Paripurna. Selanjutnya, para pengusul diberikan kesempatan untuk menjelaskan usulan mereka yang akan ditanggapi oleh fraksi-fraksi.

Rapat Paripurna kemudian akan mengambil keputusan apakah akan menyetujui usul hak menyatakan pendapat tersebut atau tidak. Apabila mulus, hak menyatakan pendapat setelah melalui proses rapatrapat dengan Presiden atau para perwakilannya, dapat berujung pada

34 Saldi Isra, "Prosedur Konstitusional Pemakzulan Presiden", makalah disampaikan dalam Seminar Nasional, Teknik Konstitusional Impeachment Presiden, Jakarta, 28 Februari 2007.

${ }^{35} \mathrm{Ibid}$. 
dua skenario yakni penyampaian pendapat ke Presiden atau masuk ke proses impeachment (pemberhentian) Presiden melalui MK.

Tata-tertib DPR itu sendiri tercantum dalam UUD 1945 pasal 189 yaitu:

1. Keputusan DPR mengenai usul menyatakan pendapat yang berupa dugaan bahwa Presiden dan/atau Wakil Presiden melakukan pelanggaran hukum berupa pengkhianatan terhadap negara, korupsi, penyuapan, tindak pidana berat lainnya atau perbuatan tercela maupun tidak memenuhi syarat sebagai Presiden dan/atau Wakil Presiden, sebagaimana dimaksud dalam Pasal 184 ayat (1) huruf c, disampaikan kepada Mahkamah Konstitusi untuk mendapatkan putusan.

2. Keputusan DPR mengenai usul menyatakan pendapat selain yang dimaksud pada ayat (1), disampaikan kepada Presiden.

Kedua, proses berlanjut ke Mahkamah Konstitusi. Dalam waktu paling lama 90 hari setelah permintaan DPR, MK wajib memeriksa, mengadili, dan memutus dengan seadil-adilnya pendapat DPR. Kemungkinan amar putusan MK adalah sebagai berikut: (i) Permohonan tidak dapat diterima, apabila permohonan tidak memenuhi syarat; (ii) Membenarkan pendapat DPR, apabila terbukti melakukan pelanggaran pasal pemakzulan; dan, (iii) Permohonan ditolak, tidak terbukti melakukan pelanggaran pasal pemakzulan. Apabila Amar Putusannya adalah alternatif kedua, maka sebagai langkah ketiga, DPR menyelenggarakan sidang paripurna untuk meneruskan usul pemberhentian kepada MPR. MPR wajib menyelenggarakan sidang untuk memutuskan usul DPR paling lambat 30 hari sejak MPR menerima usul tersebut. ${ }^{36}$

Keputusan harus diambil dalam rapat paripurna MPR yang dihadiri oleh sekurang-kurangnya $3 / 4$ dari jumlah anggota dan disetujui oleh sekurang-kurangnya $2 / 3$ dari jumlah anggota yang hadir, setelah Presiden diberi kesempatan menyampaikan penjelasan dalam rapat paripurna MPR. Jadi, putusan di MPR Mayoritas bersifat absolut.

DPR sebagai lembaga negara yang memiliki kewenangan untuk mengawasi Presiden dan dapat mengusulkan pemberhentian Presiden di tengah masa jabatannya, tentu tidak steril dari pandangan dan kepentingan politiknya, karena lembaga DPR adalah terdiri dari perwakilan partai-partai politik yang terpilih dalam pemilihan umum. Karena itu, dalam mengajukan usulan pemberhentian Presiden, DPR 
harus seobyektif mungkin dan memiliki alasan-alasan yang cukup kuat bahwa tindakan atau kebijakan Presiden benar-benar telah memenuhi dasar substansial pemberhentian Presiden (sebagaimana diatur dalam ketentuan Pasal 7A UUD 1945). Bagaimana mekanisme DPR untuk menyelidiki adanya pelanggaran yang dilakukan oleh Presiden, tidak diatur secara tegas dalam UUD. Hanya saja, Pasal 20A ayat (2) UUD 1945 memberikan hak angket kepada DPR, yaitu hak untuk melakukan penyelidikan terhadap kebijakan pemerintah yang penting dan strategis serta berdampak luas pada kehidupan masyarakat dan bangsa yang diduga bertentangan dengan peraturan perundang-undangan. ${ }^{37}$

\section{B. Pemeriksaan oleh Mahkamah Konstitusi}

Bila memperhatikan keetentuan hukum acara yang diatur dalam Undang-Undang Mahkamah Konstitusi adalah terbuka kemungkinan bagi Mahkamah Konstitusi untuk memeriksa kembali dan menilai bukti-bukti yang diajukan dan dapat memanggil asksi-saksi. ${ }^{38}$ Dengan demikian bukti-bukti yang diajukan oleh DPR dapat dinilai dan diuji kembali dan Mahkamah Konstitusi dapat memanggil kembali saksisaksi yang pernah dipanggil di DPR serta memanggil saksi-saksi yang baru. Dengan demikian dalam pemeriksaan kasus usulan pemberhentian Presiden, Mahkamah Konstitusi tidak cukup hanya dengan memeriksa dan menilai dokumen-dokumen yang disampaikan oleh DPR. Dengan mempergunakan ketentuan Pasal 86 UU Mahkamah Konstitusi, maka Mahkamah Konstitusi dapat membuat hukum acara tambahan sebagai pengaturan lebih lanjut untuk kelancaran pelaksanaan tugas dan wewenangnya. Disinilah kesempatan bagi Mahkamah Konstitusi untuk mengatur lebih lanjut mengenai hukum acara dalam hal pemeriksaan atas usulan pemberhentian Presiden oleh DPR.

Memperhatikan proses pemeriksaan pendapat DPR di Mahkamah Konstitusi dan ketentuan UUD yang menentukan bahwa Mahkamah Konstitusi "memeriksa, mengadili dan memutuskan" dapatlah

37 Undang-undang 22 Tahun 2003 tentang susunan dan kedudukan Majelis Permusyawaratan Rakyat, Dewan Perwakilan Rakyat, Dewan Perwakilan Daerah dan Dewan Perwakilan Rakyat Daerah, Pasal 28 butir b.

${ }^{38} \mathrm{Hal}$ ini dapat dilihat pada ketentuan Pasal 37 dan Pasal 38 UU Mahkamah Konstitusi yang memberikan kewenangan kepada Mahkamah Konstitusi untuk menilai buktibukti yang diajukan dan memanggil saksi maupun saksi ahli untuk hadir dan memberikan keterangan dalam sidang Mahkamah Konstitusi. 
disimpulkan bahwa sesungguhnya proses pemeriksaan pendapat DPR di Mahkamah Konstitusi adalah sebuah proses peradilan yang tidak terbatas pada pemeriksaan dokumen semata-mata. Karena itu, pemeriksaan pendapat DPR itu dapat dilakukan seperti pemeriksaan dalam perkara pidana biasa. Hanya saja posisi Presiden bukanlah seperti posisi terdakwa dalam perkara pidana, akan tetapi sebagai pihak dalam perkara yang memiliki posisinya sejajar dengan pemohonyaitu DPR yang bertindak seperti "penuntut" dalam perkara pidana. Dengan proses seperti ini, Mahkamah Konstitusi dapat secara obyektif dan secara mendalam memeriksa dan mengadili perkara yang diajukan oleh DPR, dan terhindar dari kepentingan dan pandangan politik yang dapat saja subyektif dari DPR.

Proses pemberhentian Presiden selanjutnya adalah di lembaga MPR, setelah adanya putusan Mahkamah Konstitusi yang membenarkan pendapat DPR. Apa yang terjadi di MPR sesungguhnya adalah pengambilan keputusan politik untuk menentukan apakah Presiden layak untuk diberhentikan atau tidak diberhentikan. Tidak ada pemeriksaan kembali seperti halnya yang terjadi di DPR dan Mahkamah Konstitusi. Dalam persidangan itu, MPR hanya mendengarkan pembelaan terakhir dari Presiden setelah mendengarkan usulan pemberhentian dari DPR. Perdebatan yang mungkin terjadi hanyalah perdebatan di antara anggota MPR saja.

Mahkamah Konstitusi sebagai salah satu pelaku kekuasaan kehakiman diharapkan mampu mengembalikan citra lembaga peradilan di Indonesia sebagai kekuasaan kehakiman yang medeka yang dapat dipercaya dalam menegakkan hukum dan keadilan.

Melalui lima kewenangan konstitusional yang dimilikinya, Mahkamah Konstitusi mengawal UUD 1945 dalam rangka mewujudkan cita-cita negara hukum dan negara demokrasi. ${ }^{39}$

\section{Sidang Istimewa MPR Dalam Rangka Pemakzulan}

Dalam bagian penjelasan UUD 1945 yaitu pada angka VII alinea ketiga dijelaskan bahwa "Jika Dewan menganggap bahwa Presiden sungguh melanggar Haluan Negara yang telah ditetapkan oleh Undang-undang Dasar atau oleh Majelis Permusyawaratan Rakyat, maka maka Majelis itu dapat diundang untuk persidangan Istimewa agar supaya bisa meminta pertanggung jawaban Presiden". Sedangkan

${ }^{39}$ Abdul Mukthie Fadjar, "Hukum Konstitusi dan Mahkamah Konstitusi", (Jakarta: Konstitusi Press, dan Yogyakarta: Citra Media, 2006), hal. 123. 
prosesnya adalah melalui Persidangan Istimewa MPR untuk meminta pertanggungan jawab presiden setelah adanya kesimpulan dari Dewan Perwakilan Rakyat bahwa Presiden sungguh melanggar haluan negara. Walaupun dalam penjelasan ini tidak secara eksplisit bahwa pertanggungan jawab yang ditolak oleh MPR berakibat pada diberhentikannya Presiden, namun dalam praktek ketatanegaraan Indonesia pemberhentian Presiden Soekarno dan pemberhentian Presiden Abdurrahman Wahid adalah karena pertanggungjawaban yang ditolak atau tidak mau memberi pertanggungjawaban.

Pengaturan yang mengenai pemberhentian Presiden diatur dalam ketetapan-ketetapan MPR yang menentukan bahwa MPR berwenang meminta pertanggungjawaban Presiden mengenai pelaksanaan garisgaris besar haluan negaradan menilai pertanggungjawaban tersebut serta mencabut kekuasaan dan menghentikan Presiden dalam jabatannya apabila Presiden sungguh-sungguh melanggar garis-garis besar haluan negara dan atau Undang-Undang Dasar.

Apa yang dimaksud melanggar haluan negara tidak didefinisikan dalam perundang-undangan yang ada. Namun kajian terhadap berbagai ketetapan MPR yang ada dan praktek ketatanegaraan Indonesia, pelanggaran terhadap ketetapan-ketetapan MPR baik ketetapan MPR mengenai garis-garis besar haluan negara maupun ketetapan MPR yang lainnya serta pelanggaran terhadap Undang-Undang Dasar. Jika dikaitkan dengan ketentuan Pasal 9 UUD 1945, mengenai sumpah jabatan Presiden maka pelanggaran terhadap UUD ini, dapat memperluas bentuk dan jenis pelanggaran yang dapat dilakukan oleh Presiden karena bisa mencakup tindakan Presiden yang tidak memegang teguh UUD serta tidak menjalankan segala undang-undang dan peraturannya dengan selurus-lurusnya. Adanya kata-kata "menjalankan undang-undang dan peraturannya dengan seluruslurusnya", dapat berarti bahwa pelanggaran terhadap setiap ketentuan undang-undang termasuk perundang-undangan hukum pidana atau pelanggaran terhadap peraturan pemerintah, keputusan Presiden dan peraturan-peraturan lainnya dapat diartikan sebagai pelanggaran terhadap Pasal 9 UUD 1945.

Ketentuan yang lebih rinci mengenai mekanisme pemberhentian Presiden diatur dalam Ketetapan MPR RI No.VI/MPR/1973 dan Tap MPR No.III/MPR/1978, yang menegaskan bahwa DPR berkewajiban setiap saat mengawasi tindakan-tindakan Presiden dalam rangka pelaksanaan haluan negara. Apabila DPR menganggap bahwa Presiden sungguh-sungguh melanggar haluan negara maka DPR menyampaikan memorandum untuk mengingatkan Presiden. Apabila dalam kurun 
waktu tiga bulan presiden tidak memperhatikan memorandum tersebut, maka DPR menyampaikan memorandum kedua. Dan apabila dalam waktu satu bulan memorandum kedua ini tidak diindahkan presiden maka DPR dapat meminta MPR untuk mengadakan Sidang Istimewa untuk meminta pertanggungjawaban Presiden. ${ }^{40}$

Ukuran yang paling penting dalam mengukur kesalahan atau pertanggungjawaban Politik Presiden adalah Kejujuran dan kesungguhan Presiden dalam melaksanakan amanat Konstitusi, melayani kepentingan rakyat, kepentingan bangsa dan negara. Termasuk dalam pengertian ini adalah kesungguhan dan kejujuran Presiden dalam menjalankan kewajiban konstitusionalnya sesuai dengan sumpah jabatannya sebagai Presiden yaitu untuk menghormati UUD dan menjalankan undang-undang dan peraturannya dengan selurus-lurusnya serta mengabdikan kepada bangsa dan negara.

\section{Penutup}

Amandemen terhadap UUD 1945 secara mendasar telah mengubah ketentuan tentang alasan, tahapan, dan tata cara pemberhentian Presiden dan/atau Wapres di tengah masa jabatan. Dengan demikian bisa ditarik kesimpulan bahwa yang menjadi alasan utama pemakzulan kedua presiden tersebut yakni karena presiden kehilangan legitimasi karena tindakan dan perbuatannya yang dapat dikategorikan sebagai perbuatan melanggar hukum baik hukum pidana maupun hukum ketatanegaraan/pelanggaran konstitusi termasuk pelanggaran sumpah jabatan. Hampir mirip dengan praktek di Amerika Serikat, tetapi nyatanya alasan itu masih cukup rancu. Kerancuan itu sepertinya yang mendasari terbitnya perubahan ketiga UUD 1945. UUD 1945 lepas dari perubahan ketiga terlihat berusaha mengatur dengan tegas alasan-alasan pemakzulan Presiden. Hal ini memang berbeda dengan UUD 1945 sebelum perubahan yang tidak mengatur dengan tegas pemberhentian presiden di masa jabatannya termasuk alasan-alasannya.

Pelanggaran hukum lain di luar pelanggaran terhadap undang-undang hukum pidana seperti pelanggaran terhadap UUD dan kewajiban-kewajiban konstitusionalnya sebagai presiden serta pelanggaran terhadap nilai-nilai agama, moral dan adat dapat dijadikan alasan untuk memberhentikan presiden di tengah masa jabatannya, asalkan pelanggaran itu sedemikian rupa merendahkan martabat dan kedudukan Presiden.

${ }^{40}$ Zoelva, Op. Cit., hal. 91. 


\section{Daftar Pustaka}

Aidul, Fitriciada. Reformasi Pemilu dan Agenda Konsolidasi Demokrasi, Jurisprudence, Vol. 1 No.2, September 2004.

Alrasid, Harun. Pengisian Jabatan Presiden, Jakarta: Pustaka Utama Grafiti, 1999.

Asshiddiqie, Jimly, Hukum Tata Negara dan Pilar-pilar Demokrasi, Jakarta: Konstitusi Press, 2006.

. Konstitusi dan Konstitusionalisme Indonesia, Jakarta: Konstitusi Press, 2006.

. Perkembangan dan Konsolidasi Lembaga Negara Pasca Reformasi, Jakarta: Konstitusi Press, 2006.

. Sengketa Kewenangan Konstitusional Lembaga Negara, Jakarta: Konstitusi Press, 2006.

Fadjar, A. Mukhtie. Hukum Konstitusi dan Mahkamah Konstitusi, Jakarta: Konstitusi Press, 2005.

Harun, Refly, et.al.(ed.). Menjaga Denyut Konstitusi, Jakarta: Konstitusi Press, 2004.

Isra, Saldi. "Prosedur Konstitusional Pemakzulan Presiden", makalah disampaikan dalam Seminar Nasional, Teknik Konstitusional Impeachment Presiden, Jakarta, 28 Februari 2007.

Lijphardt, Arend (Penyadur: Ibrahim R. Dkk.). Sistem Pemerintahan Parlementer dan Presidensial, Jakarta: Raja Grafindo Persada, 1995.

Manan, Bagir. Lembaga Kepresidenan, Yogyakarta: PSHUII dan Gama Media, 1999.

Mulyosudarmo, Suwoto. Peralihan Kekuasaan, Kajian Teoretis dan Yuridis terhadap Pidato Nawaksara, Jakarta: Gramedia, 1997.

Siahaan, Maruarar. Hukum Acara Mahkamah Konstitusi, Jakarta: Konstitusi Press, 2005.

Soekanto, Soerjono. Pengantar Penelitian Hukum, cet. 3, Jakarta: Penerbit Universitas Indonesia-UI Press, 1986.

Zoelva, Hamdan, (ed. Nur Rosihin Ana). Impeachment Presiden: Alasan Tindak Pidana Pemberhentian Presiden Menurut UUD 1945, Jakarta: Konstitusi Press, 2005. 